\title{
POLÍTICAS PÚBLICAS E AS LIÇÓES PRELIMINARES DA COVID-19: ANÁLISE COMPORTAMENTAL, DIREITO DO CONSUMIDOR E A ECONOMIA DO CUIDADO
}

\author{
PUBLIC POLICIES AND THE INTRODUCTORY LESSONS OF COVID-19: BEHAVIORAL \\ ANALYSIS, CONSUMER LAW AND THE ECONOMICS OF CARE
}

Diógenes Faria de Carvalho

Pós-Doutor em Direito pela Universidade Federal do Rio Grande do Sul (UFRGS),

Presidente do Instituto Brasileiro de Política

e Direito do Consumidor (BRASILCON)

dfcarvalho01@hotmail.com

Vitor Hugo do Amaral Ferreira

Doutorando em Direito pela Universidade Federal do Rio Grande do Sul (UFRGS) Secretário-Geral do Instituto Brasileiro de Política e Direito do Consumidor (BRASILCON) vitorhugodir@hotmail.com

Em tempos de pandemia, o que conhecíamos apenas em ficção ou relatos distantes da contemporaneidade, os agentes políticos se colocam no desafio de criar medidas que minimizem os efeitos, uma vez que evitá-los é impossível.

As políticas públicas enfrentam a urgência em açōes que contemplem os aspectos sociais e econômicos. Estamos diante, entre outras circunstâncias, da suspensão das aulas em escolas e universidades, do fechamento do comércio, da proibição de eventos em massa, do distanciamento social e da limitação de fluxo em aeroportos.

Medidas interventivas sempre serão instrumentos de força e de autoridade, que justificam a atuação do Direito Administrativo, quando necessário, e a razão de ser do Estado, principalmente em momentos de crise mundial e pandemia. As medidas tornam-se necessárias para o combate da discriminação da COVID-19.

Os estudos de economia comportamental, em especial do nudge, que é uma técnica de conformação de escolhas a um comportamento-alvo e possível aos formuladores de políticas para enquadrar as opçóes envolvidas em determinado processo de tomada de decisão, pode estimular a adoção de uma conduta desejável, saudável e segura.

Assim, o nudge oferece uma estrutura que possibilita a mudança dentro da tomada de decisóes dos envolvidos, a fim de obter alteraçóes em seus comportamentos e atitudes, o 
que constituiria melhorias para eles próprios e para a sociedade como um todo. O nuding é uma das descobertas da Economia Comportamental, que se baseiam extensivamente em suposiçóes da psicologia comportamental e sobre suas heurísticas e vieses, e que já foram aplicadas a uma série de problemas atuais. $\mathrm{O}$ termo nudge nos leva à necessidade de definir também o que é entendido por Arquitetura de Escolha.

Este termo também foi definido como uma espécie de estímulo. É qualquer aspecto da arquitetura de escolhas capaz de mudar o comportamento das pessoas de forma previsível sem vetar qualquer opção e sem nenhuma mudança significativa em seus incentivos econômicos.

A economia comportamental emerge como uma importante estratégia a ser adotada em políticas públicas para mudar o comportamento do cidadão. Os agentes de políticas públicas podem ser bem-sucedidos em levar os cidadãos ao comportamento cívico, caso sigam a arquitetura cognitiva da escolha que estes enfrentam no dia a dia e principalmente em momentos de crise.

A arquitetura da escolha começou sendo utilizada principalmente para elaboração de políticas públicas na Inglaterra, Estados Unidos e Austrália, por equipes governamentais (Behavioural Insights Team, Social and Behavioral Sciences Team e Behavioural Economics Team of the Australian Government, respectivamente) que ficaram conhecidas como nudges unit (equipe de cutucóes). No entanto, aos poucos foi sendo aplicada por consultorias ao comportamento do consumidor pelo marketing, comportamento do colaborador pela gestão de pessoas. Hoje, as unidades governamentais têm se referido aos "nudges" de forma mais ampla, como insights comportamentais (behavioral insights), termo que frequentemente é encontrado no nome dessas entidades, como no pioneiro Behavioural Insights Team, criado no Reino Unido em 2010, e que serviu de estudo para diversas iniciativas semelhantes em outros países.

Em síntese, a economia comportamental confere cientificidade à fragilidade cognitivacomportamental dos cidadáos; ela permite, também, a identificação dos padróes de comportamento, com intuito de subsidiar as políticas públicas em relação à formulação de leis e medidas de intervenção administrativa. Ao funcionamento do cérebro resta comprovada a confusão própria da condição humana, pois somos engenhosos em algumas coisas e muito inábeis em outras. Somos extremamente inteligentes, ao mesmo passo limitados em racionalidade.

Contudo, o objetivo do estudo da tomada de decisão, tomando-se como referência o fato de estarmos diante da pandemia da COVID-19, exige escolha ou mesmo determinação pelo isolamento, afastamento social, limitação e fracionamento de produtos, fechamento de serviços, novos hábitos de higiene, o que reforça o papel das emoçóes em face das relaçóes com diferentes níveis de realidade e o modelo de tomada de decisão.

Regiôes do país com maior índice de população idosa, caso da região sul, determinaram a restriçáo da circulaçáo de pessoas acima de 60 anos. O Decreto do Executivo Municipal, em Porto Alegre/RS, por exemplo, determina que os idosos somente poderão deixar suas residências em caso de consultas médicas, exames, vacinação e compras de produtos alimentícios e de farmácia, com previsão de multa em caso de descumprimento. 
O comportamento oferece convincentes vieses, ou seja, erros sistemáticos no julgamento e nas decisões, nesta tendência dos cidadãos em náo se adaptarem às necessidades da crise. Muitos insights comportamentais são relevantes para uma análise da situação da pandemia e de como pensar em tratar esse problema. A multa imposta no decreto em comento induz a um comportamento pela lógica racional, que sem a multa, poderia, em muitos casos, manter idosos ainda nas ruas de Porto Alegre, motivados pelos impulsos emocionais.

A dicotomia entre a razão e a emoção é própria dos humanos - este processo dual que hoje se estuda nos processos cognitivos e afetivos envolvidos na tomada de decisão. É por estes sistemas que o cidadão está avaliando a sua situação na crise de pandemia, ao questionar se deve respeitar o isolamento social, ainda que unânimes as orientaçóes de médicos, biólogos e especialistas da área da saúde; ao não fazer a higiene correta das mãos; ao usar máscaras fora do contexto; comprar remédios para prevenir a COVID-19; estocar alimento; gerar um comportamento compulsivo nas redes sociais e ir ao hospital sem grandes sintomas.

A revelaçáo do comportamento náo somente sugere que os cidadáos laborem sob uma variedade de poderosos preconceitos e crenças, mas que a libertação destes preconceitos é difícil, se não impossível. Condutas como a comprometedora superconfiança persistem insistentemente, mesmo quando as pessoas são alertadas sobre as incisivas probabilidades de eventos adversos. Por certo, quando as pessoas superestimam sua imunidade individual contra danos, pode ser que deixem de tomar medidas sensatas de prevençáo. Se estiverem correndo riscos por causa do otimismo irreal, podem se beneficiar de um nugde. Assim, se as pessoas são constantemente lembradas dos números e de eventos ruins do COVID em outros países, podem diminuir o nível de otimismo.

Somos agentes econômicos, as naçóes se potencializam como instrumentos de poder também diante da sua força financeira. Podemos falar em uma sociedade do consumo impactada por uma sociedade econômica e vice-versa. Novas são as economias que conjugam um espaço mais leve diante da rigidez da economia clássica baseada na produção material.

A ordem atual modificou o jeito de fazer as coisas. Negócios digitais móveis e transmissão de pensamentos em tempo real criaram a tecnologia disruptiva (termo que define a inovação de um produto, ou serviço, com particularidades de provocar uma ruptura aos padrōes já estabelecidos no mercado). As novas economias, entre elas a digital, ampliam o acesso em um tempo de produçáo desmaterializada, o que permite o surgimento de uma economia criativa e, por consequência, a economia de acesso, que proporciona, por sua vez, a economia de compartilhamento, que passa a exigir um cuidado com os bens e ambientes compartilhados, surgindo assim a economia da confiança.

De modo geral, o cenário que se projeta, necessariamente incerto, pois não se tem a dimensão dos efeitos finais, em todas as ordens, da COVID-19, irá trazer consigo o amadurecimento da economia do cuidado, consubstanciado à reconstrução do bem-estar das pessoas. Em sentido restrito, um dos setores que sinaliza cuidado advém das relaçóes de consumo. Algumas medidas serão duras, porém legítimas se ao fim o objetivo for de 
promover o bem-estar, o cuidado.

O quadro atual oferece um panorama geral da falibilidade humana, bem como demonstra que pessoas são influenciadas por nudges. Se o objetivo é proteger as pessoas da COVID-19, por que não ir além? Será que ordenar e proibir não são atitudes legítimas? Se os humanos de fato cometem erros sistemáticos, por que não protegê-los e proibi-los de errar? O ideal é apostar nas pesquisas empíricas das ferramentas da economia comportamental para o bem-estar da populaçáo e conscientização do imenso problema da pandemia mundial. A cooperação e boa-fé são uma valência para enfretamento da COVID-19.

A vulnerabilidade como base principiológica sempre esteve presente ao se justificar a proteção aos mais frágeis, ao exemplo de consumidores e trabalhadores. A contemporaneidade está fazendo entender que somos, como nunca, todos vulneráveis, alguns ainda mais. Outros que tinham a condiçáo de vulnerar, passam a entender o que é estar também em condições de vulnerabilidade, seguindo o exemplo anterior, os fornecedores e empregadores. As políticas públicas que estarão por vir devem entender a ruptura de paradigmas e o futuro do Direito do Consumidor terá que se valer em construir um espaço de cuidado como a primeira lição da COVID-19. Nova política, capaz de cuidar das mazelas sociais em consonância aos efeitos econômicos, levando em consideração que a maior das consequências da pandemia será a humana. 